\section{Pharmaceutical research}

\section{New tenants}

The Swiss pharmaceutical company Sandoz has decided to set up a new research institute in the neurosciences at University College, part of the University of London. According to Mr E.J. Fullagar, director of Sandoz's UK operations, the new institute reflects the company's belief in the quality of British researchers - it hopes to recruit almost all its staff in Britain - and in the continuance of top quality British research. But the institute may help to persuade the British regulatory authorities to view more favourably applications for price increases on Sandoz's products.

The new institute, the first that Sandoz has set up on a university campus, is an experiment. According to Mr Fullagar, the venture will be no less expensive than building an institute on Sandoz's own premises. The hope is that spin-off from close links with the college will more than pay for any extra costs incurred.

The company chose to site its institute at University College partly because the two have collaborated successfully in the past on clinical studies and partly because the college's research in the neurosciences matches its own interests. The new institute will be chiefly concerned with the role of neurotransmitters and neuromodulators in the nervous system.

Although the institute will be entirely independent of the college, employing

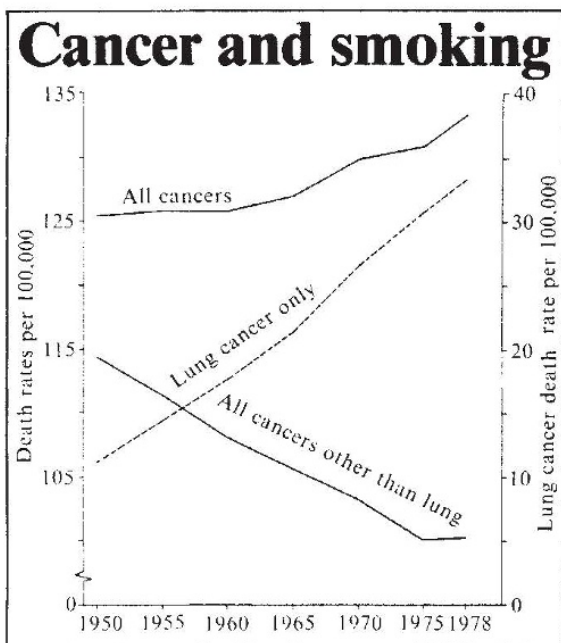

As shown in the figure, published in "The Health Consequences of Smoking: Cancer 1982"' (US Department of Health and Human Services), during the period 1950 to 1978 , the overall cancer death rate increased. This trend results from a remarkable increase in lung cancer death rates. However, if lung cancer deaths are excluded, the overall cancer mortality rate has fallen. This is largely a result of improved diagnosis, treatment and survival times for cancer sites not associated with cigarette smoking, such as prostatic, colorectal and breast cancers, while lung cancer survival remains dismal. about 60 of its own research staff, the plan is that there should be a close relationship between the research staffs and that the college might look to some institute staff for teaching.

The college, which although relatively well endowed is nevertheless suffering from university cutbacks, will benefit financially. Although Sandoz's rent is only nominal, the company will pay the college a $£ 2.5$ million premium and thereafter pay for overheads and services such as library and catering facilities. The money will help the college out of some of its difficulties, in particular those of completing capital projects abandoned because of cuts in its grants from the University Grants Committee. Thus work begun on a new chemistry building in the early 1970s will now be completed. Sandoz will refurbish the building vacated when the chemistry department moves into the new building to be used by the new institute.

Sandoz estimates that it will spend $£ 5$ million on setting up the institute, divided equally between payments to the college, the costs of refurbishing and the cost of equipping laboratories. The laboratories will not be ready before September 1983 at the earliest. Hence, according to $\mathrm{Mr}$ Fullagar, it is still too early to describe the research programme in detail, or to say whether the college and institute will cooperate on joint programmes and, if so, how. Patents taken out on the results of research supported entirely by the institute will, however, belong to Sandoz. But where research has been jointly supported, the college's lawyers will advise.

Sandoz, therefore, seems cheerful about the long-term prospects of British university research. Its view, however, is not shared by Biogen, the Swiss-based pharmaceutical company, which has chosen not to site its third laboratory in Britain on the grounds that the university cuts may irreparably damage British biotechnological research.

Biogen plans to set up a new laboratory along the lines of those at Cambridge, Massachusetts, and Geneva. The idea is that the laboratory should be separate from but near to a university department with considerable expertise in recombinant DNA research. The company says that it cannot justify setting up a laboratory near a suitable British university because no department is guaranteed to escape the ill effects of the university cuts. So it is looking elsewhere, in particular in Belgium and West Germany.

The new laboratory is intended to complement the work of Biogen's existing laboratories and to allow the company to spread its research between institutions employing no more than 75 research staff. According to Walter Gilbert, Biogen's chief executive, Biogen will nevertheless consider employing British biotechnologists of suitable calibre who apply for posts in any of its laboratories.

Judy Redfearn

\section{Pesticide data}

\section{Row on access}

\section{Washington}

The latest move in the lengthy battle over access to scientific data on the medical effects of pesticides came last month with the US Environmental Protection Agency (EPA) asking Congress for authority to write its own rules for the release of such information. Members of the House of Representatives' Agriculture Committee have tried to find a compromise between public interest groups demanding open access to the data submitted to the agency and pesticide manufacturers, who argue that the unrestricted release of such information would benefit their commercial competitors.

The manufacturers have been pushing for changes in the Federal Insecticide, Fungicide and Rodenticide Act (FIFRA), first passed by Congress in 1972, which provides any individual with access under the Freedom of Information Act to scientific and medical data submitted to EPA as part of the regulatory process of registering a new chemical. Attempts at revision are being fought by a coalition of health groups, conservationists and labour unions which argues that the demands being made by industry would make it impossible, for example, for research scientists to communicate openly the results of their analysis of the data.

In its zeal to respond to public protests about the potential health hazards of new pesticides, Congress passed in 1978 stiff new amendments to FIFRA. These included a specific clause saying that data on the medical effects of a pesticide were not to be treated as a trade secret, and were not therefore exempt from freedom-ofinformation requests.

Since then, manufacturers working primarily through their Washington-based lobbying organization, the National Agriculture Chemicals Association (NACA), have tried to challenge the clause several times in court. The companies claim that the data produced in their research laboratories are private, and that the government's requirement that they be handed out on demand is a violation of constitutional rights.

So far, the courts have upheld the validity of the new law. The manufacturers have responded by turning their attention first to Congress, in the hope of having the law revised, and more recently to EPA with the prospect of receiving a more sympathetic hearing.

Last summer Mr George Brown, previously a prominent member of the House Science and Technology Committee and now chairman of the research subcommittee of the House Agriculture Committee, introduced a new bill that would limit the conditions under which the data could be released. These revisions would make the data available only to approved 
individuals, who would have to take notes from reports made available in EPA reading rooms. Labour union representatives and people working in the health services would be able to borrow complete reports, but would not be allowed to divulge the contents to others. No employee of another chemical manufacturing company would be allowed access to the data; and nobody would be allowed to make a complete transcript of the research reports.

Members of the subcommittee staff argue that such provisions, provide a compromise between industry's desire to protect confidential research data, and the public's right to information on the risks and benefits of chemicals used for crop protection. Both parties in the dispute disagree.

The manufacturers were initially enthusiastic about the changes proposed by Mr Brown, but their support has evaporated as the amendments have been revised to take into account some of the objections of those claiming to be defending the public interest.

Environmentalists and labour union groups are seizing this "window of opportunity" between the failure of the last industry challenge and the eventual tightening up of administrative requirements to get as much information on existing pesticides out of EPA as they can. EPA administrator Anne Gorsuch informed a coalition of such groups that the agency intended to respond to demands for pre-registration data on eleven chemicals as well as data on alternatives to 2,4,5-T.

At the same time, EPA has been talking with industry representatives, who have asked for an "administrative stay" on the release of data under the Freedom of Information Act, and are said to be helping EPA to develop a set of restrictions that would be both legally defensible and commercially acceptable.

David Dickson

\section{Moves in Mongolia}

The new president of the Mongolian Academy of Sciences is Dr Choydogiyn Tseren, a 42-year-old physicist. Dr Tseren, who is a graduate of Moscow University, has spent a considerable time (1966 to 1971 and 1974 to 1980) at the International Nuclear Research Institute at Dubna. In 1980, he returned to Mongolia to become academic secretary of the academy.

Dr Tseren's appointment as president of the academy, which was effected by a special decree of the presidium of the People's Great Khural (parliament) of Mongolia, followed the dismissal, at the beginning of the year, of the previous president, Dr B. Shirendev, for his "misunderstanding" of the nature of socialism, a term which apparently covered hard currency irregularities.

Vera Rich

\section{Coal gasification}

\section{Belgian first}

\section{Brussels}

A gleam of hope for Europe's coal production came with the announcement this month that the first gasification of coal at depths of nearly 1,000 metres would take place this May in Belgium. The technique has been used for some time in the Soviet Union and in other countries but never at these depths. If the project at Thulin near the French border lives up to its promise it will turn many of the inaccessible or abandoned coal deposits in Europe into a new source of energy.

The Thulin project is run by the Institute for the Development of Subterranean Gasification, 60 per cent of whose funds are provided by the Belgian and German governments, the other 40 per cent by the EEC.

The retrocombustion technique used works by burning the coal in situ and then pushing the gas through the coal strata to a second outlet. The creation of such a circuit at this depth means working with high pressures and ensuring that the coal is permeable enough to allow the passage of the gas to the second bore hole. Air is forced down the first bore hole and ignited at a temperature of some $400^{\circ} \mathrm{C}$, so that the coal ignites spontaneously.

The problem is that the deeper the coal lies the further away the second bore hole must be. At 1,000 metres, the gas would have to travel between 80 and 100 metres. The costs rise with the depth of coal deposits, as it becomes increasingly difficult to complete the circuit. Oil can be extracted at depths as low as 4,000 metres, but with coal the deeper one goes the more impermeable it is. At Thulin the problem has been overcome by forcing compressed air along the vein in order to enlarge the existing natural fissures.

The commercial applications of the technique are still uncertain, as it depends not only on energy prices but also on the coal seam thickness. Nevertheless, the British Coal Board is following the experiments with interest as a potential means of exploiting North Sea coal.

So far the gasified coal being brought to the surface in Belgium is of low quality, yielding some $2,500-3,000 \mathrm{kcal}$ per $\mathrm{m}^{3}$. However, specialized treatment could increase this to $12,500 \mathrm{kcal}^{\mathrm{c}} \mathrm{per} \mathrm{m}^{3}$. At first, therefore, the gasified coal would simply be burnt in power stations but there is speculation that it could one day compete with pressurized liquid gas - now used to run cars.

The earliest date by which the technique could bring commercial benefits is put at 1990. Nonetheless the Belgian energy minister, Etienne Knoops, seizing on a spark of optimism to brighten his country's current troubles, remarked, "We are today inaugurating the birth of a new natural source of riches for our country".

Jasper Becker
Dutch energy policy

\section{Talking shop}

\section{Waalre, The Netherlands}

The steering group set up in The Netherlands to referee the national debate on the country's energy problems now finds itself grappling with financial constraints - and with some political disenchantment.

The long-running and often acrimonious Dutch energy debate began in the early seventies with the government's "energy memorandum", but got under way in earnest only last June, with the appointment of a nine-strong steering group of politicians, energy experts, scientists and labour union representatives, given the brief of organizing the public discussion.

Some years ago, a budget of $£ 3.5$ million (Dfl.17 million) was allotted to the steering group to cover total costs for the two-year discussion, and the group now has a staff of 14 academics (including a theologian) and 17 administrators. Most of the money was intended for subsidies to the various groups in society seeking to work out alternative energy policies to that put forward by the government.

In January this year the steering group awarded a first round of grants, totalling $£ 1.5$ million, to 31 groups including a consortium of 50 environment groups and employers' organizations. This was only half the amount asked for by the applicants, and reflects the financial pressures being felt by the steering group. In February the government decided on a budget of around $£ 5.5$ million for the steering group instead of the $£ 7.4$ million requested, of which $£ 1.8$ million is

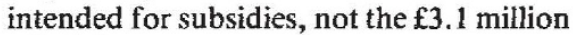
asked for.

Discussions on the budget revealed political discontent over the policies of the steering group, discontent which at one time threatened to bring an early end to the project. Some members of parliament and press commentators were critical of the way in which the first batch of subsidies was allocated - in particular, complaining that too much money (roughly half the total) went to pro-nuclear groups having close ties with industry, and in no desperate need of the cash.

The "information phase" of the discussion is now due to be completed by the end of 1982. The aim of this part of the process is, in the words of steering-group chairman Maurits De Brauw, a former minister for science policy, "to give the public the unique chance to present alternative, scientifically based policy ideas, equivalent to those of the establishment". When that is over, a further short public discussion will follow, probably concentrating on three or four energy/economy scenarios selected from the initial phase.

Whether or not this attempt at involving all segments of Dutch society in a major 